http://jmscr.igmpublication.org/home/ ISSN (e)-2347-176x ISSN (p) 2455-0450

crossref DOI: https://dx.doi.org/10.18535/jmscr/v9i12.31

\title{
Unsupervised Pills: Who are Likely to Consume?
}

\author{
Authors
}

\author{
Dr Neha Singh ${ }^{1}$, Dr Meenakshi Rana ${ }^{2}$, Dr Sanjay Rathod ${ }^{3}$ \\ 1,2,3 Junior Resident Department of Obstetrics and Gynecology, IGMC Shimla \\ Corresponding Author \\ Dr Meenakshi Rana \\ Junior Resident, Department of Obstetrics and Gynecology, IGMC Shimla, India
}

\begin{abstract}
Background: Federation of obstetrics and gynecological societies of indi(FOGSI) recommends close monitoring of distribution of drugs that are used for medical abortion and that the medical profession and pharmaceutical industry should excise due diligence in the promotion and usage of drugs that are used for medical abortion. Despite this, it has been perceived by the society that, medical abortion are extremely safe option even in hands of untrained personel, leading to its over the counter dispensing and possibly increase in unsupervised terminations and life threatening complications.

Objective: To Study the demographic profile of women consuming unsupervised abortion pills

Study Design: Prospective Observational Study

Study Settings: This study is to be conducted at Kamla Nehru State Hospital for Mother and Child, IGMC Shimla.

Study Period: $1^{\text {st }}$ July 2018 - 30 $0^{\text {th }}$ June 2019

\section{Inclusion Criteria}

All women who have consumed unsupervised abortion pills and reported to the hospital.

\section{Exclusion Criteria}

Women coming with Spontaneous abortion, Missed abortion and Blighted ovum.

Results: Data was collected from 121 patients who had history of self medication of abortion pills.74\% women were in age group 21-30 years and $88.4 \%$ were married. uneducated women were $5 \% .93 \%$ were multigravidas. Source of procurement of drug was seen to be chemist in $79.3 \% .7(6 \%)$ of the patients in the study used the pills between 9-12 weeks of gestation and another 13(11\%) used it after 12 weeks. Conclusion: Health care and health protection is every women's right. Every women must be counseled regarding advantages, drawbacks, risk and limitations of different method of abortion. awareness on contraceptives is must for all. The chemist also needs to be aware about the MTP act and consequences of medicines that are taken without medical supervision. training on various regimes and advancement is also required for the medical practitioner.
\end{abstract}

\section{Introduction}

Abortion has been practiced over ancient times by means of various methods. Laws, cultural and religious views related to abortion are different all around the world and have evolved over various eras.
Abortion is a willful termination of pregnancy beyond period of viability. ${ }^{1}$ Medical abortion is defined by World health organization as "Usage of pharmacological drugs to terminate pregnancy". 2 World health organization defines unsafe abortion as a procedure for terminating an unwanted 
pregnancy either by persons lacking the necessary skills or in environment lacking minimal medical standards or both. ${ }^{3}$ Abortion has been legal in India for over four decades since the introduction of Medical termination of pregnancy act $1971 .^{4}$ The goal of act was to regulate and ensure access to safe abortion ${ }^{4}$ and thus protect women from "Inflicted pregnancies" and "Forced motherhood". It was amended in years 2003 and medical method of abortion using Mifepristone and Misoprostol was approved as legal method for termination of early pregnancy. ${ }^{5}$

It has been seen that half of the unintended pregnancies (nearly 46 million) are terminated every year worldwide. ${ }^{6}$ Unsafe abortion is associated with higher maternal morbidity and mortality accounting to around $13 \%$ of maternal death worldwide. ${ }^{7}$ Mortality attributed to unsafe abortion is estimated to be around 47,000 women per year. ${ }^{8}$ The number of induced abortions in India in approved centers is estimated to be $6,20,472$ and the maternal mortality due to unsafe abortions is $8 \%$ as reported in the family welfare statistics 2011.9,10 Thus unsafe abortion is a persistent but preventable pandemic.

Abortion can be done by two methods either by surgical method or by medical method. Medical abortion is a safe method of termination of pregnancy when performed as per guidelines, it has a success rate of $95-99 \%{ }^{1}$. It is a preferred method for abortion due to its confidentiality and safety it offers and in being non surgical method. Surgical method of termination increases the risk of uterine perforation, cervical laceration, hemorrhage, infection, future miscarriages and sterility and thus medical abortion becomes a better and safer alternative of abortion. ${ }^{11}$
Documenting such indiscriminate use of medical method of abortion and determining its social implications is necessary as this is a significant health problem, keeping in view these facts a study was done in The Department of Obstetrics and Gynecology, Kamla Nehru State hospital for Mother and Child, IGMC, Shimla to analyze the complications of administration of unsupervised abortion pills and to suggest measures to prevent such practices.

\section{Methodology}

The present prospective observational study was conducted in Kamla Nehru State Hospital for Mother and Child, IGMC Shimla w.e.f. $1^{\text {st }}$ July 2018 - 30 ${ }^{\text {th }}$ June 2019.

\section{Inclusion Criteria}

All women who had consumed unsupervised abortion pills and then reported to the hospital.

\section{Exclusion Criteria}

Women who came with Spontaneous abortion, Missed abortion and Blighted ovum.

\section{Material and Methods}

A participant's information cum Consent form was distributed to prospective participants. data was collected from patients who fulfilled the inclusion criteriae and reported to hospital after self medication of abortion pills.

After admission General physical examination, Systemic, Abdominal and Pelvic examination was done as per proforma.

\section{Results}

A total of 121 women reported to the hospital with intake of unsupervised abortion pills.

Table 1: Age wise distribution

\begin{tabular}{|l|c|c|c|c|}
\hline Serial number & Age(years) & $\begin{array}{c}\text { Number } \\
\mathrm{n}=121\end{array}$ & Percentage & 95\% confidence limits \\
\hline 1 & $<=20$ & 12 & $10 \%$ & $5.23-16.68 \%$ \\
\hline 2 & $21-25$ & 43 & $36 \%$ & $27.05-44.75 \%$ \\
\hline 3 & $26-30$ & 46 & $38 \%$ & $29.35-47.29 \%$ \\
\hline 4 & $31-35$ & 12 & $9.9 \%$ & $5.23-16.68 \%$ \\
\hline 5 & $>35$ & 8 & $7 \%$ & $2.90-12.61 \%$ \\
\hline
\end{tabular}


As shown in Table 1, a total of 121 cases were studied who came with unsupervised abortion pills intake, out of which $12(10 \%)$ were below or equal to 20 years of age, $43(36 \%)$ were between
21-25 years. It was observed that maximum $46(38 \%)$ were in age group of 26-30 years. $12(9.9 \%)$ were in age group of 31-35 years. Only $8(7 \%)$ cases were $>35$ years of age.

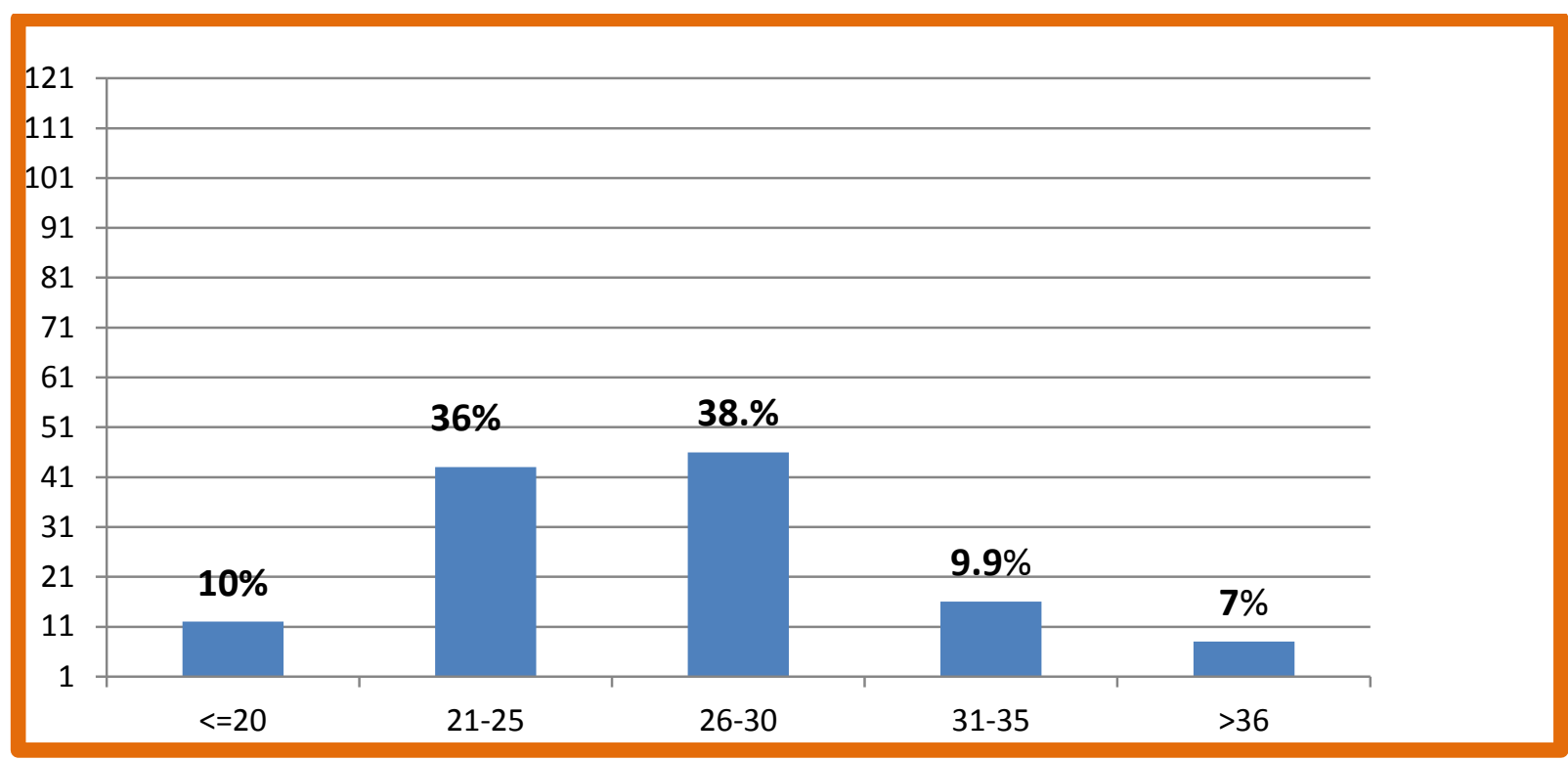

Figure 1: Age wise distribution

Table 2: Gestation at which pill consumed

\begin{tabular}{|l|c|c|c|c|}
\hline Serial number & Gestation in weeks & $\begin{array}{c}\text { Number } \\
\mathrm{n}=121\end{array}$ & Percentage & $95 \%$ confidence limits \\
\hline 1 & $<9$ weeks & 101 & $83.4 \%$ & $75.63-89.60 \%$ \\
\hline 2 & $9-12$ weeks & 7 & $5.7 \%$ & $2.36-11.56 \%$ \\
\hline 3 & $>12$ weeks & 13 & $10.7 \%$ & $5.85-17.67 \%$ \\
\hline
\end{tabular}

Table 2 shows the gestation at which the abortion pills were consumed. Majority of cases i.e. 102(84\%) consumed MTP pill at gestation less than 9 weeks which is the recommended gestation, followed by $13(11 \%)$ on more than 12 weeks gestation and $7(5.7 \%)$ cases consumed pills in the gestation of 9-12 weeks .

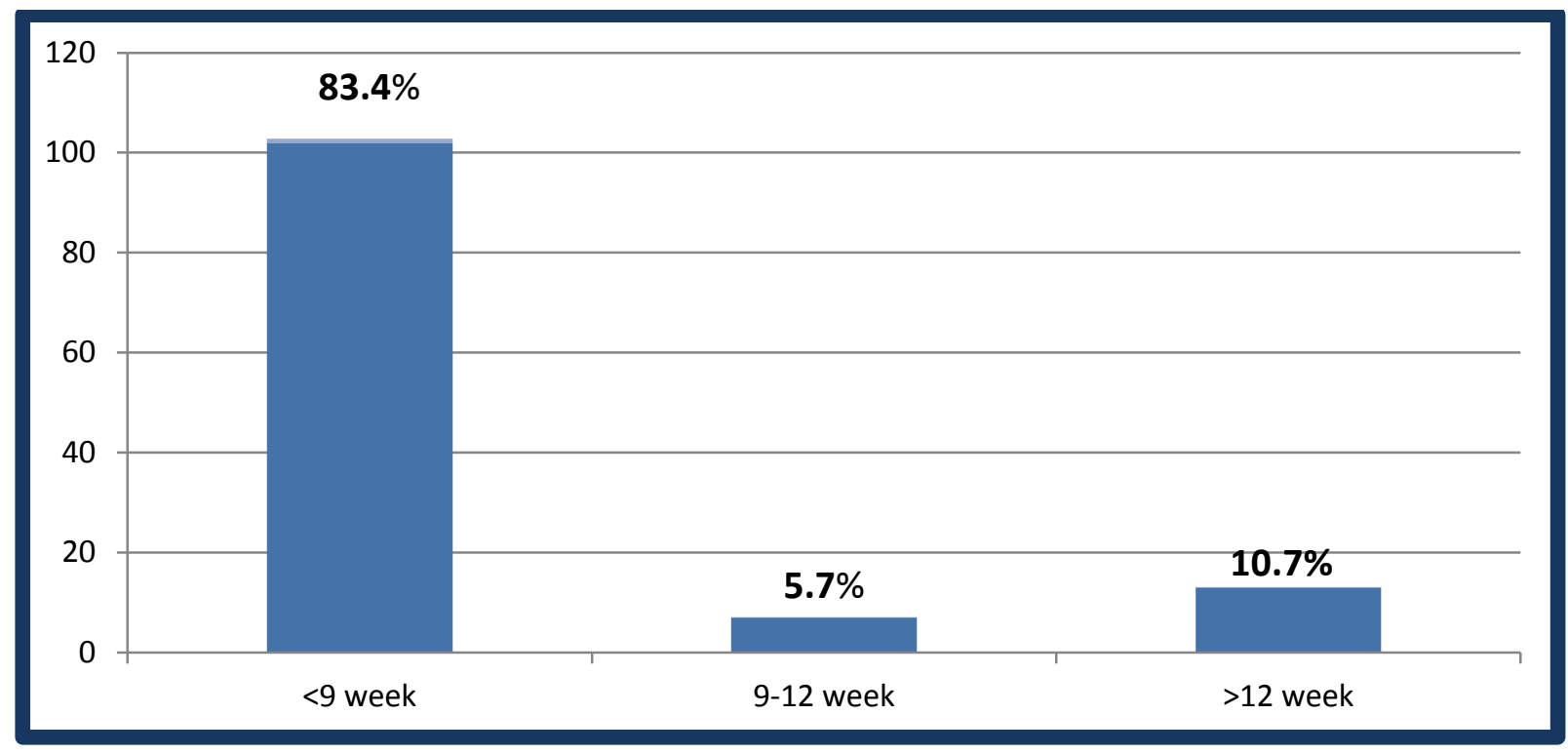

Figure 2: Period of gestation at which pills consumed 


\section{JMSCR Vol||09||Issue||12||Page 181-190||December}

Table 3: History of Contraception usage

\begin{tabular}{|l|c|c|c|c|}
\hline $\begin{array}{l}\text { Serial } \\
\text { number }\end{array}$ & $\begin{array}{c}\text { Contraception } \\
\text { used }\end{array}$ & $\begin{array}{c}\text { Number } \\
\mathrm{n}=121\end{array}$ & Percentage & $\begin{array}{c}\text { 95\% Confidence } \\
\text { limits }\end{array}$ \\
\hline 1 & No & 118 & $98 \%$ & $0.51-7.07 \%$ \\
\hline 2 & Yes & 3 & $2 \%$ & $92.93-99.49 \%$ \\
\hline
\end{tabular}

Table 3 shows that out of 121 cases studied contraception (oral contraceptive pills) and $118((98 \%)$ did not have any history of conceived after contraception failure. contraception, while only $3(2 \%)$ had history of

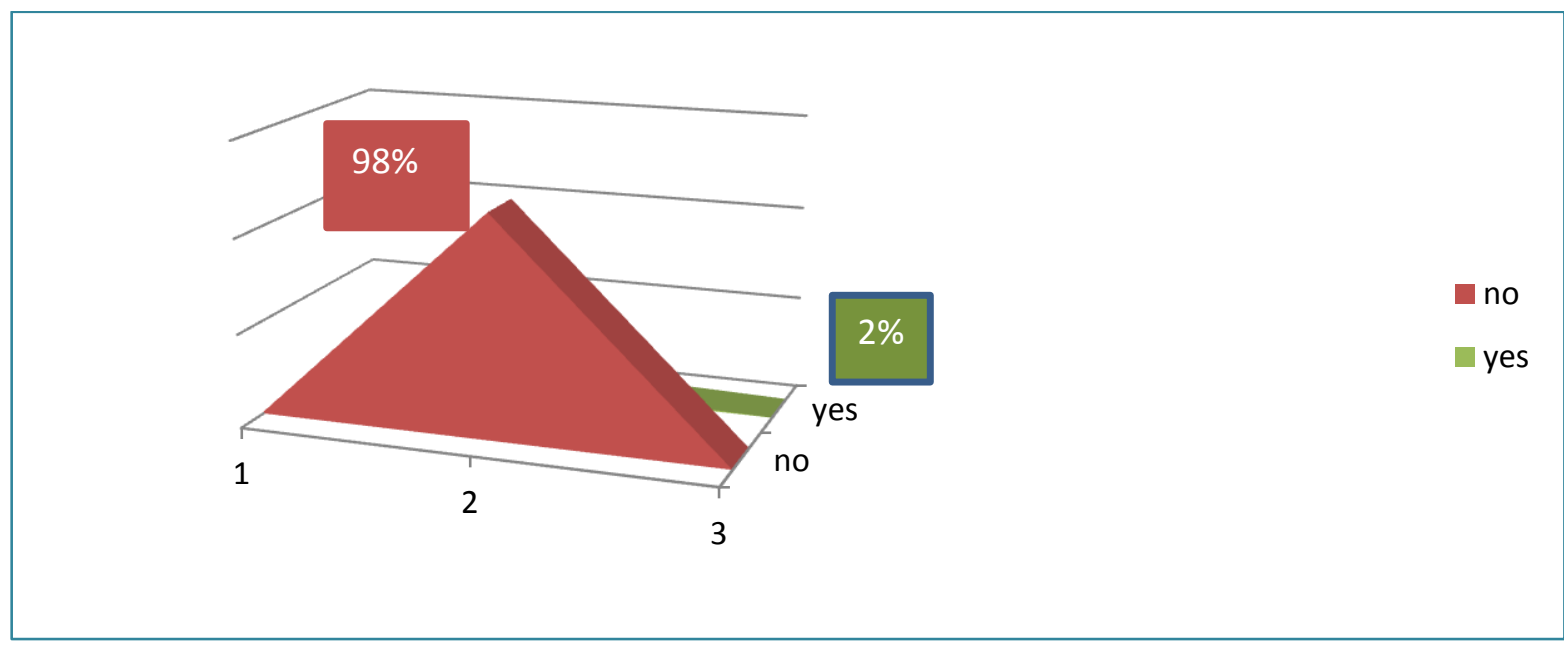

Figure 3: Distribution of cases according to history of contraception usage

Table 4: Gravidity of patient

\begin{tabular}{|l|c|c|c|c|}
\hline $\begin{array}{l}\text { Serial } \\
\text { number }\end{array}$ & Gravida & $\begin{array}{c}\text { Number } \\
\mathrm{n}=121\end{array}$ & Percentage & $\begin{array}{c}95 \% \text { Confidence } \\
\text { limits }\end{array}$ \\
\hline 1 & Primigravida & 8 & $7 \%$ & $2.90-12.61 \%$ \\
\hline 2 & 2 & 37 & $31 \%$ & $22.53-39.61 \%$ \\
\hline 3 & 3 & 45 & $37 \%$ & $28.58-46.44 \%$ \\
\hline 4 & 4 & 23 & $19 \%$ & $12.45-27.14 \%$ \\
\hline 5 & $>4$ & 8 & $7 \%$ & $2.90-12.61 \%$ \\
\hline
\end{tabular}

Table 4: It was observed that out of 121 cases only $8(7 \%)$ were primigravida. Maximum intake was cases having parity 2. $23(19 \%)$ and $8(7 \%)$ were seen in multigravidae, amongst which 37 (31\%) cases having 4 and more than 4 parity were cases having parity one and 45(37\%) were respectively. This shows the usage of pills as substitute to contraception.

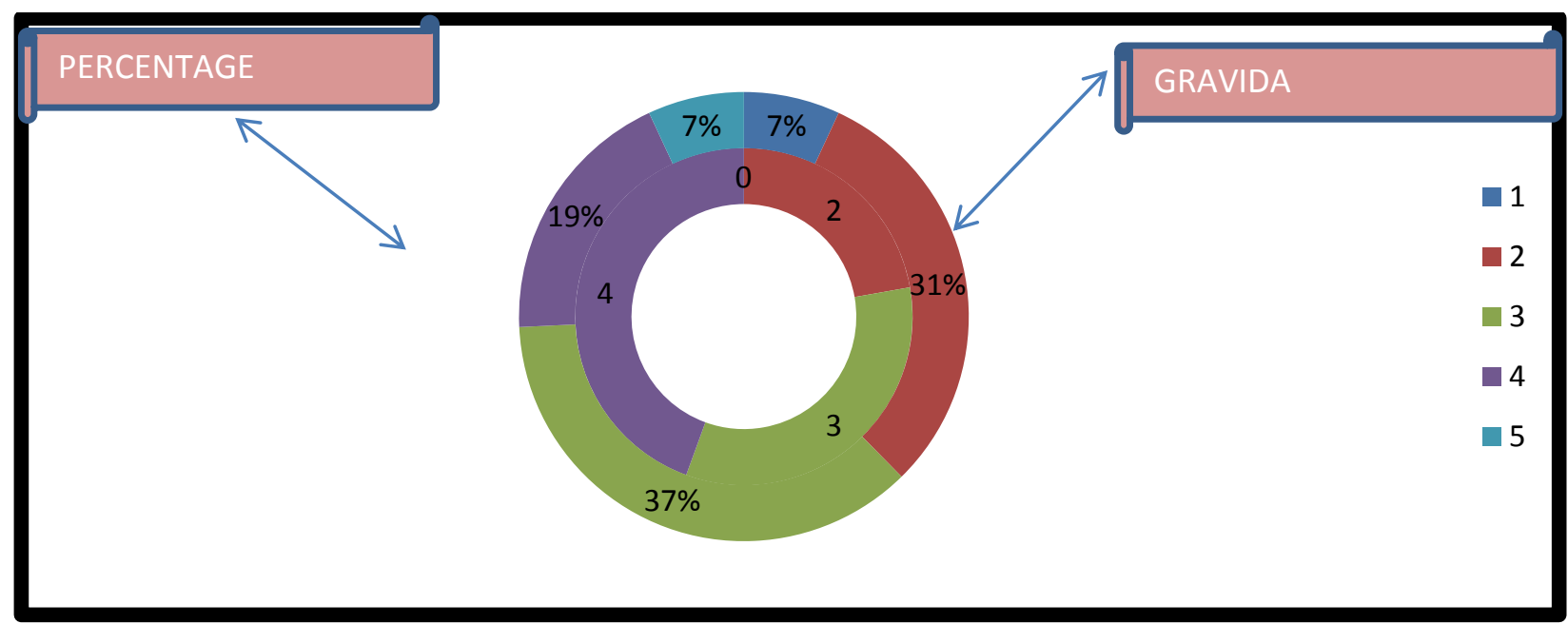

Figure 4: Distribution according to gravidity 
Table 5: Distribution according to education level

\begin{tabular}{|l|c|c|c|c|}
\hline $\begin{array}{l}\text { Serial } \\
\text { number }\end{array}$ & Education & $\begin{array}{c}\text { Number } \\
\mathrm{n}=121\end{array}$ & Percentage & $\begin{array}{c}95 \% \text { Confidence } \\
\text { limits }\end{array}$ \\
\hline 1 & uneducated & 6 & $5 \%$ & $1.84-10.48 \%$ \\
\hline 2 & Primary & 3 & $2 \%$ & $0.51-7.07 \%$ \\
\hline 3 & Middle & 24 & $20 \%$ & $13.14-28.06 \%$ \\
\hline 4 & secondary & 34 & $28 \%$ & $20.31-36.9 \%$ \\
\hline 5 & Higher secondary & 37 & $31 \%$ & $22.53-39.61 \%$ \\
\hline 6 & College & 17 & $14 \%$ & $8.40-21.54 \%$ \\
\hline
\end{tabular}

Table 5: It was observed that maximum cases $37(31 \%)$ consuming unsupervised pills were educated till higher secondary school. 34(28\%) went to school till secondary class, 24(20\%) were

educated till middle school, 17(14\%) were educated till college and $3(2 \%)$ till primary school. Uneducated were $6(5 \%)$ which were migrant labourer from Nepal and Bihar.

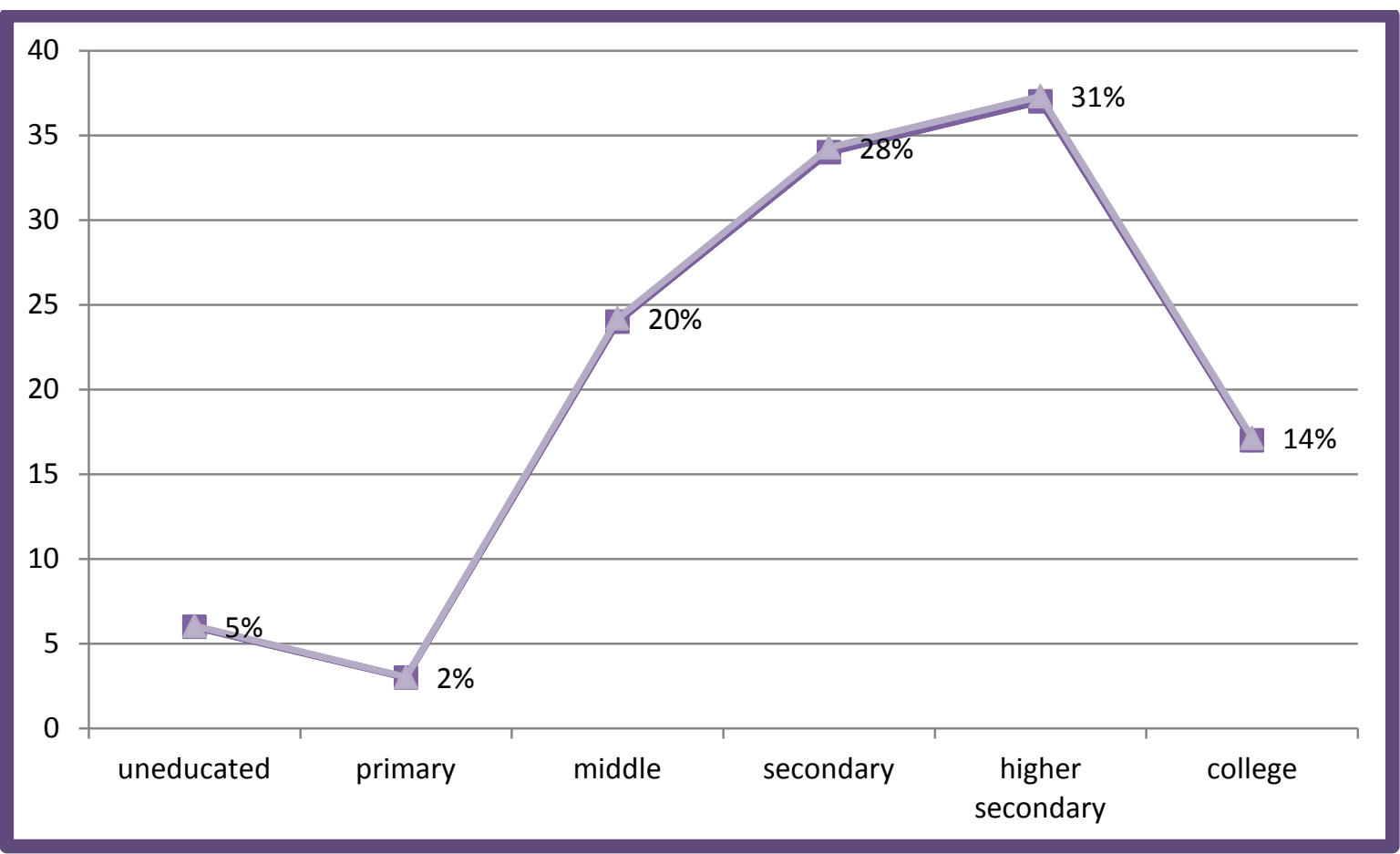

Figure 5: Distribution of cases according to education level

Table 6: Distribution according to Socioeconomic status

\begin{tabular}{|l|c|c|c|c|}
\hline $\begin{array}{l}\text { Serial } \\
\text { number }\end{array}$ & Class & $\begin{array}{c}\text { Number } \\
\mathrm{n}=121\end{array}$ & Percentage & $\begin{array}{c}95 \% \text { Confidence } \\
\text { limits }\end{array}$ \\
\hline 1 & lower & 17 & $14 \%$ & $8.40-21.54 \%$ \\
\hline 2 & Lower upper & 49 & $40.4 \%$ & $31.67-49.80 \%$ \\
\hline 3 & Middle upper & 46 & $38 \%$ & $29.35-47.29 \%$ \\
\hline 4 & Middle & 7 & $5.7 \%$ & $2.36-11.56 \%$ \\
\hline 5 & Upper & 2 & $1.6 \%$ & $0.20-5.84 \%$ \\
\hline
\end{tabular}

Table 6 classify cases into different socioeconomic status, showing that maximum cases 49(40.4\%) consuming unsupervised MTP belonged to lower upper class, $46(38 \%)$ belonged to middle upper, 17(14\%) belonged to lower class. The lowest number was seen belonging to middle class i.e. 7(5.7\%) and upper class 2(1.6\%). 


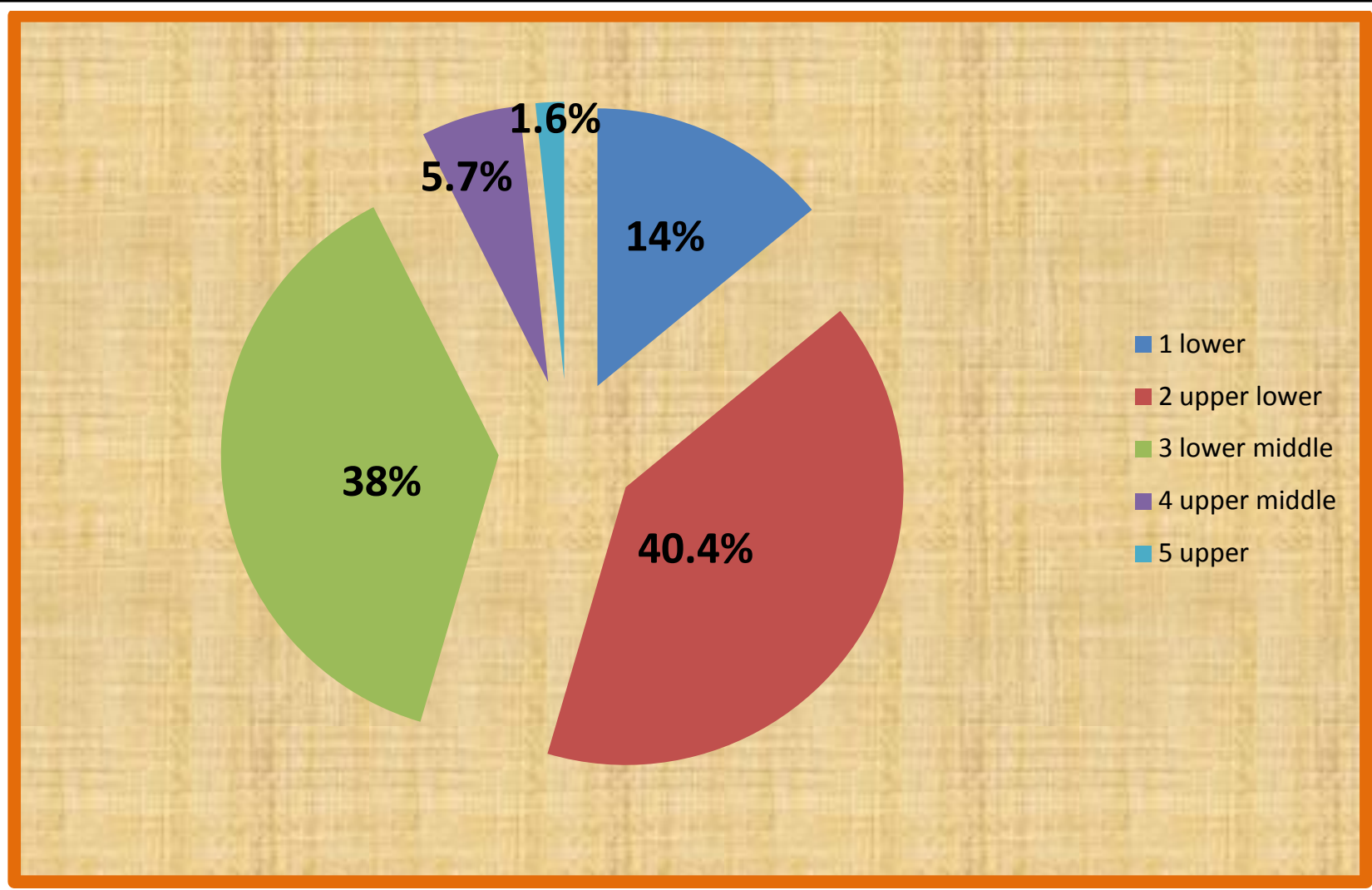

Figure 6: Distribution of cases according to socioeconomic status

Table 7: Source of procurement of abortion pills

\begin{tabular}{|l|c|c|c|c|}
\hline $\begin{array}{l}\text { Serial } \\
\text { number }\end{array}$ & Source & $\begin{array}{c}\text { Number } \\
\mathrm{n}=121\end{array}$ & Percentage & $\begin{array}{c}\text { 95\% Confidence } \\
\text { limits }\end{array}$ \\
\hline 1 & Chemists & 96 & $79.3 \%$ & $71.03-86.16 \%$ \\
\hline 2 & Private practitioner & 25 & $20.6 \%$ & $13.84-28.97 \%$ \\
\hline
\end{tabular}

Table 7 shows the source from where the abortion pills were procured. The source was found to be chemists in $96(79.3 \%)$ cases, while $25(20.6 \%)$ cases took it from private practitioner who were not licensed under the MTP act to give abortion pills.

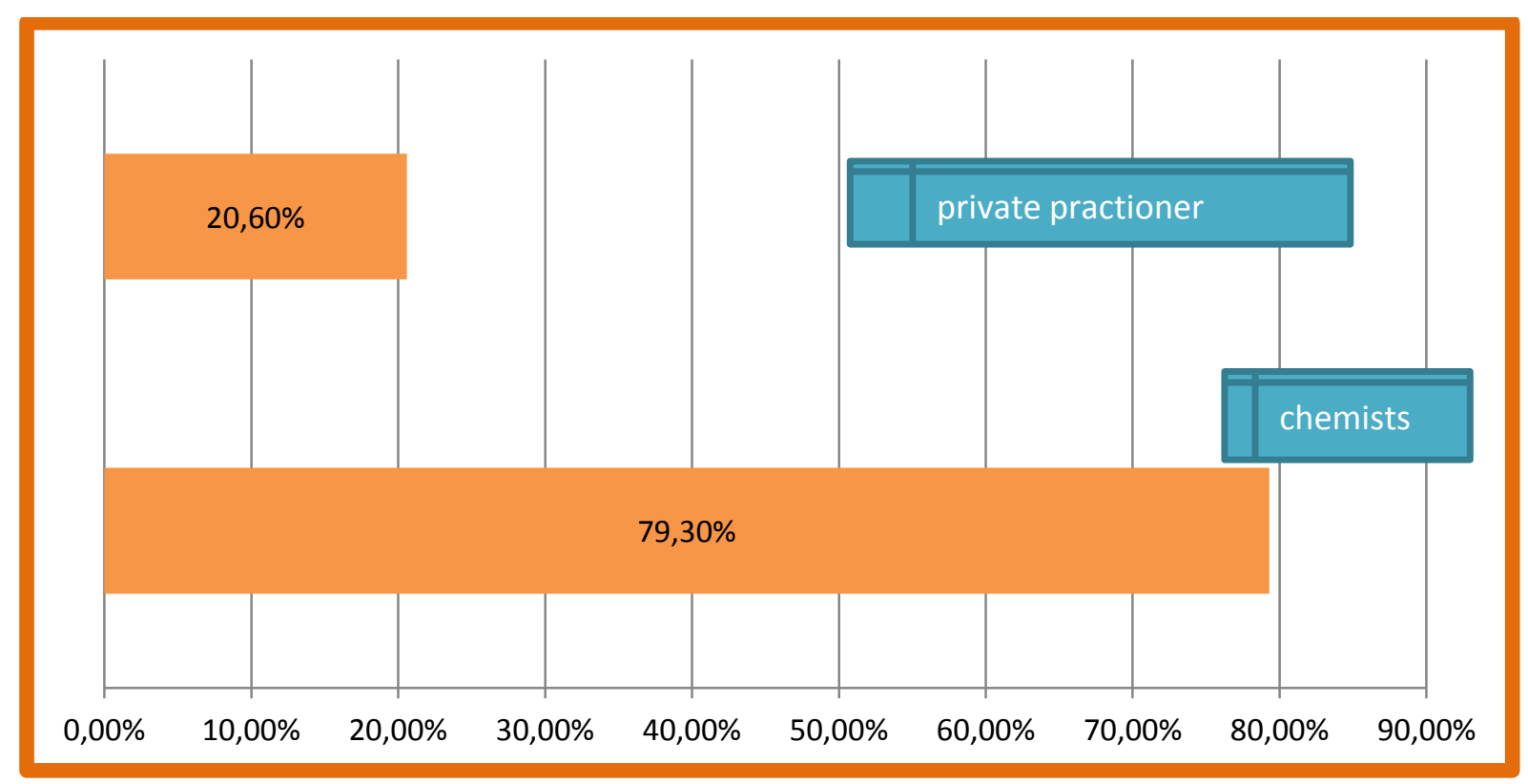

Figure 7: Source of procurement of abortion pills 
Table 8: Marital status

\begin{tabular}{|l|c|c|c|c|}
\hline $\begin{array}{l}\text { Serial } \\
\text { number }\end{array}$ & Marital status & $\begin{array}{c}\text { Number } \\
\mathrm{n}=121\end{array}$ & Percentage & $\begin{array}{c}95 \% \text { Confidence } \\
\text { limits }\end{array}$ \\
\hline 1 & Unmarried & 14 & $11.5 \%$ & $6.47-18.65 \%$ \\
\hline 2 & Married & 107 & $88.4 \%$ & $81.53-93.53 \%$ \\
\hline
\end{tabular}

Table 8: The intake of unsupervised pills was only $14(11.5 \%)$ cases of unmarried women observed to be more in married women cumulating to $107(88.4 \%$ ) cases, while there were consuming pills. It suggests its usage in getting rid of unplanned pregnancy.

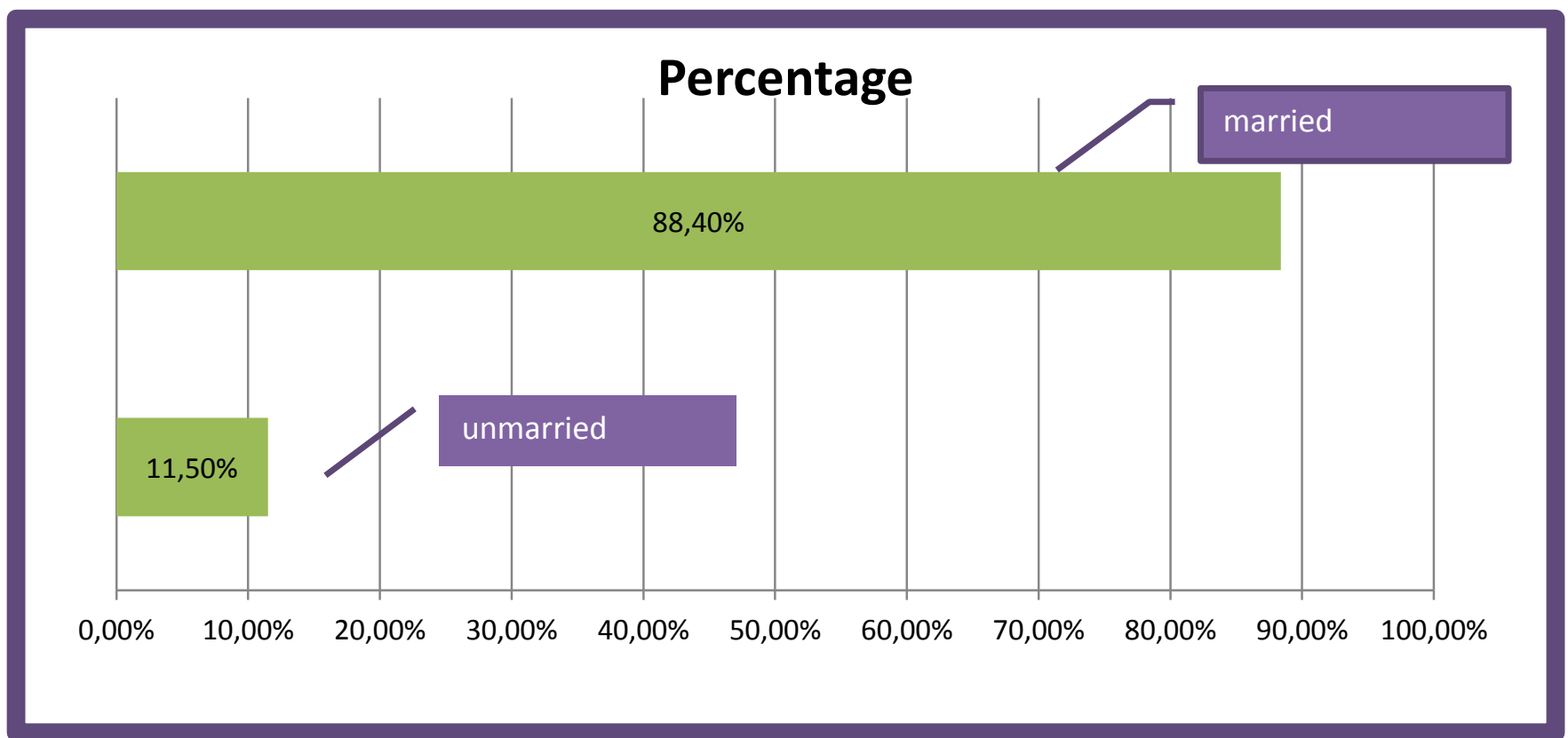

Figure 8: Distribution according to marital status

Table 9: Demographic profile

\begin{tabular}{|l|c|c|c|c|}
\hline $\begin{array}{l}\text { Serial } \\
\text { number }\end{array}$ & Demography & $\begin{array}{c}\text { Number } \\
\mathrm{n}=121\end{array}$ & Percentage & $\begin{array}{c}95 \% \text { confidence } \\
\text { limit }\end{array}$ \\
\hline 1 & Rural & 66 & $55 \%$ & $45.24-63.62 \%$ \\
\hline 2 & Urban & 55 & $45 \%$ & $36.38-54.76 \%$ \\
\hline
\end{tabular}

Table 9: It was seen that maximum intake of abortion pills was found in rural population area. It could be because of maximum population $66(55 \%)$ while $55(45 \%)$ cases belonged to urban of Himachal Pradesh residing in rural area.

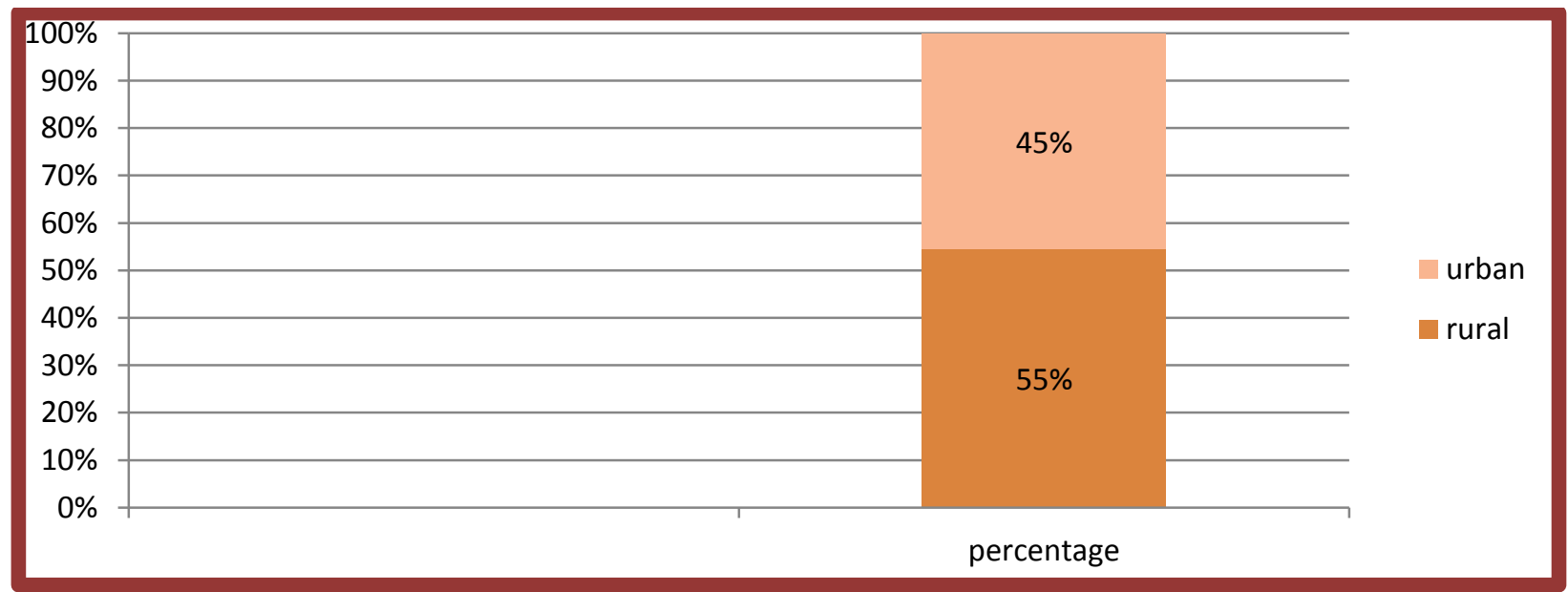

Figure 9: Distribution of cases according to demographic profile 
Table 10: Prior pregnancy confirmation with USG/ bimanual examination

\begin{tabular}{|l|c|c|c|}
\hline $\begin{array}{l}\text { Ultrasound/Per vaginum } \\
\text { examination }\end{array}$ & $\begin{array}{c}\text { Number } \\
\mathrm{n}=121\end{array}$ & Percentage & $\begin{array}{c}95 \% \text { confidence } \\
\text { limits }\end{array}$ \\
\hline Nothing done & 91 & $75 \%$ & $66.54-82.60 \%$ \\
\hline Ultrasound done & 28 & $23 \%$ & $15.96-31.68 \%$ \\
\hline Bimanual examination done & 2 & $2 \%$ & $0.20-5.84 \%$ \\
\hline
\end{tabular}

Table 10: Recommendation clearly state that either bimanual examination or ultrasound should be done before prescribing pills but neither of these were done in $91(75 \%)$ cases. Only $28(23 \%)$ had an ultrasound done prior to intake and only $2(2 \%)$ had bimanual examination done before consumption of pills.

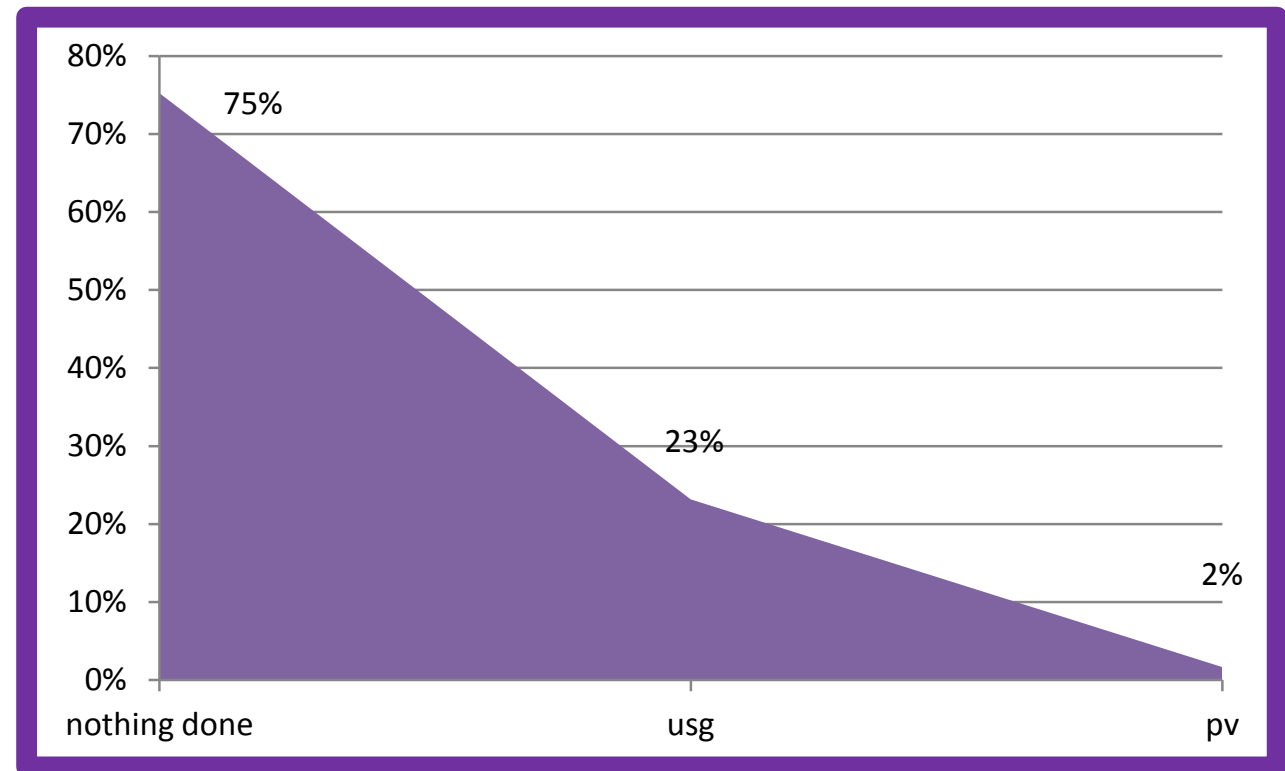

Figure 10: Prior Pregnancy confirmation before consumption of pills

Table 11: Distribution of cases according to correct regimen of abortion pills

\begin{tabular}{|l|c|c|c|c|}
\hline Serial number & Medicine & $\begin{array}{c}\text { Number } \\
\mathrm{n}=121\end{array}$ & Percentage & $\begin{array}{c}95 \% \text { confidence } \\
\text { limits }\end{array}$ \\
\hline 1 & Incorrect regime & 84 & $69.5 \%$ & $60.39-77.47 \%$ \\
\hline 2 & Correct regime & 37 & $30.5 \%$ & $22.53-39.61 \%$ \\
\hline
\end{tabular}

Table 11 shows that out of 121 cases the correct regimen of Mifepristone followed by Misoprostol 4 tablets intake after 48 hours was seen in $37(30.5 \%)$ cases. Incorrect regimen was found in $84(69.5 \%)$ cases in which it was seen that Mifepristone followed by Misoprostol after $24 \mathrm{hrs}$ was seen in $47(38.8 \%)$ cases. History of Mifepristone followed by incomplete dosage of Misoprostol was seen in 11(9\%) cases. The intake of only Mifepristone and only Misoprostol was seen in $16(13.2 \%)$ cases and $10(8.2 \%)$ cases respectively. 


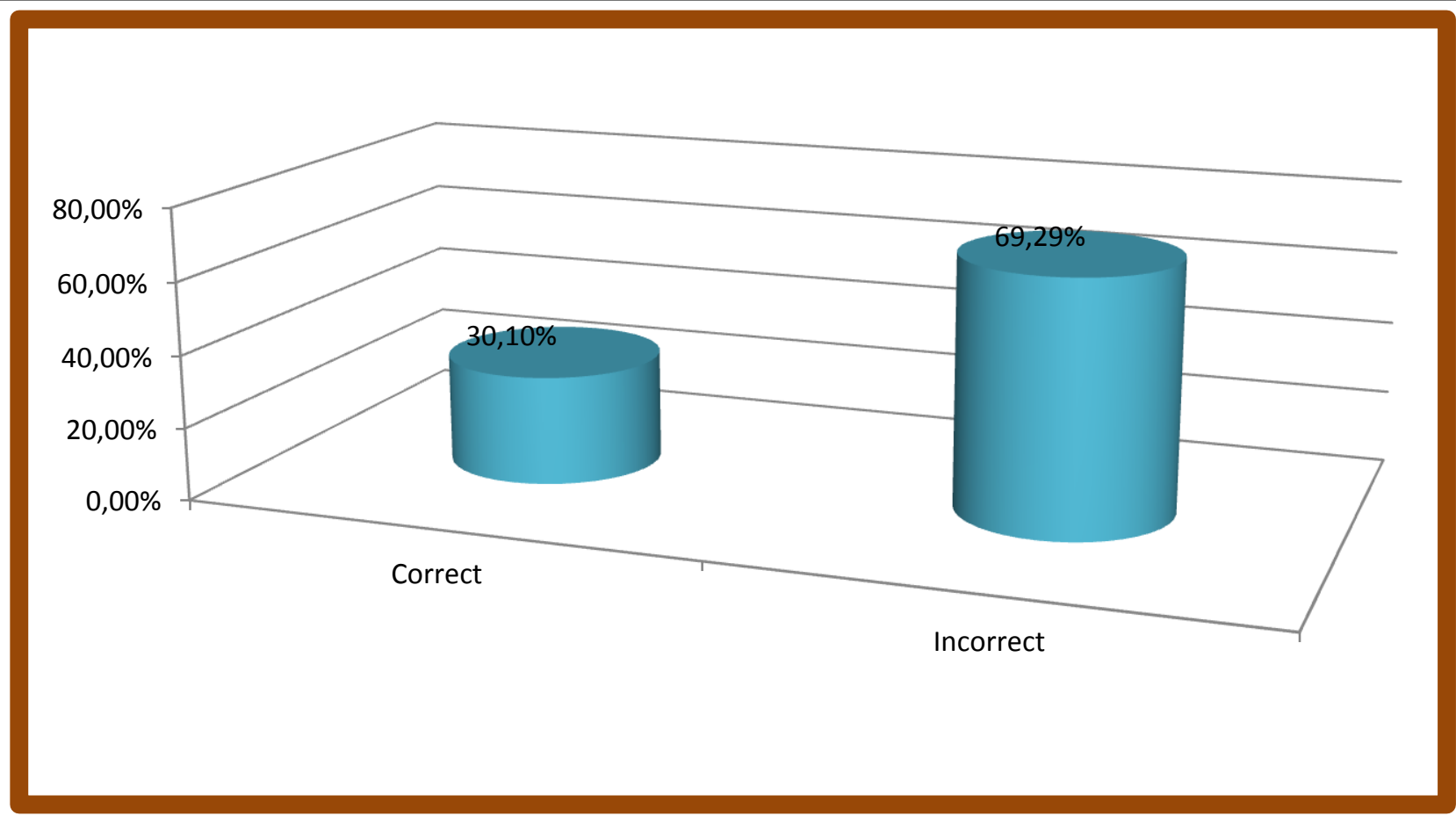

Figure 11: Distribution of cases according to regimens

\section{Discussion}

A prospective observational study was conducted in the Department of Obstetrics and Gynecology, Kamla Nehru State hospital for Mother and Child, Indira Gandhi Medical College Shimla w.e.f. $1^{\text {st }}$ July 2018 to $30^{\text {th }}$ June 2019 . A total of 121 women reported to the hospital after consumption of unsupervised abortion pills. Most of the pill consumers i.e. $89(74 \%)$ cases were in age group of 21-30 years. Married women 107 (88.4\%) showed the maximum consumption of pills. Multigravidae constituted 113 (94\%) of the total cases and maximum $45 / 121$ i.e. $37 \%$ cases among them were Para 2. The pharmacist was the main source of procurement of drug in $96(79.3 \%)$ cases. Majority cases i.e. 49 (40\%) belonged to lower upper class. Majority cases $37 / 121$ i.e. $31 \%$ were educated upto higher secondary. Most cases $101(83.4 \%)$ consumed pills at the recommended period of gestation (within 9weeks) while intake of pills in $2^{\text {nd }}$ trimester was found in $13(10.7 \%)$ cases. Majority of cases i.e. 91 (75\%) did not have pregnancy confirmation with either bimanual examination or ultrasound before consumption of pills. Major proportion of cases belonged to rural areas $66(55 \%)$. Incorrect regimen of intake of pills was seen in $84(69.5 \%)$ cases.

\section{Conclusion}

Health care and Health protection is every women's right. The ability to decide if a woman wants to carry pregnancy or terminate it, is one of the important reproductive rights she holds. When women and girls can access effective contraception and safe abortion services, they are better able to safeguard their health and well being. Any procedure done beyond the bounds of law is considered unsafe, but to what magnitude and degree of unsafety it entails is what present study shows.

Medical abortion is a safe method of termination of pregnancy if a holistic approach is applied.

It starts with awareness on contraceptives which should be must for all reproductive age groups, Proper counseling of the women who wants to terminate pregnancy regarding advantages, disadvantages, risk and limitation of different method of abortion should be done.

The chemist also needs to be aware about the MTP act and consequences of medicines that are taken without medical supervision. A small warning label on the combipack can also be considered.

The change in scenario in form of shifting trend of pills used for getting rid of unwanted pregnancy to 
becoming pills for contraception is alarming and needs to be seriously addressed. More and more studies and surveys needs to be carried out.

\section{Bibliography}

1. Munshi KS, Thaker RV, Shah JM, Mewada BN. Self-medication of abortion pills and its complication: an observational study. Int J Reprod Contracept Obstet Gynecol 2018; 7:205-9.

2. Agarwal M, Datta A. How safe are over the counter abortion pills-differences between its intended and practical usage and its implications- a study conducted in a tertiary care centre in Shillong, Meghalaya, India. Int J Reprod Contracept Obstet Gynecol 2016; 5:3036-4.

3. Sarojini, Ashakiran TR, Bhanu BT, Radhika. Over the counter MTP pills and its impact on Women's Health. J Obstet Gynecol India 2017; 67(1):37-41.

4. Government of India. The Medical Termination of pregnancy act, no.34;1971. Available from: http://tcw.nic.in/acts/MTPact-1971. Pdf Assessed on 26/06/2018.

5. Government of India. The medical Termination of pregnancy Rules (Amendment); 2002. Available from: https://mohfw.gov.in/acts-rules-andstandards-health.../acts/MTP-actamendment-2002. Assessed on June 26, 2018.

6. Singh B, Garg R, Kaur P, Kaur B, Kumari S. Abuse of MTP pill without prescription: an analytical study. European J Pharmacet Med Res 2017; 4(8):357-61.

7. Giri A, Srivastav VR, Suwal A, Sharma B. A study of Complications following self administration with Medical Abortion Pills. Nepal J Obstet Gynecol 2015; 19(1):20-4.
8. Ahman E, Shah IH. New estimates and trends regarding unsafe abortion mortality. Int J Gynecol Obstet 2011; 115(2):121-6.

9. Nivedita K, Shanthini F. Is it safe to Provide Abortion Pills over the counter? A Study on Outcome Following Self Medication with Abortion Pills. J Clin Diagn Res 2015; 9(1):01-4.

10. Family welfare statistics in India. Ministry of Family Welfare and Health, Govt. Of India, 2011. Available from http://www.mohfw.nic.in/WriteRead Data/1892s/3503492088 FWStatistics 2011 Revised 3110 11.pdf.

11. Bajwa SK, Bajwa SJS, Ghai GK, Singh N, Singh A, Goraya SPS. Medical abortion: Is it a blessing or curse for the developing nations?. Srilanka J Obstet Gynecol 2011; 33(3):84-90. 